\title{
WOMEN ISSUES IN HILLARY CLINTON'S SPEECHES
}

\author{
Elsa Emiria Leba
}

\begin{abstract}
Women's rights to contribute freely in many life spheres are now granted by law. Yet, Hillary Clinton as a U.S. prominent politician still discusses about women's issues in her speeches. This article discusses about Hillary's views, types, and solutions of women's issues that are found in her political speeches from the year 2007 until 2013.

This research is conducted under American Studies applying an interdisciplinary approach, which uses anthropology, sociology, and historical-biographical disciplines, as well as reconciliation of tenses approach that bridges past, present, and future. The data are selected based on purposeful sampling with maximum variation sampling is used as the approach to show various perspectives about women's issues in Hillary's speeches.

The research finds that Hillary considers it important to overcome women's issues in all life spheres; education, economy, health, politics, and social that emerge due to the patriarchal system. It also finds that Hillary regards all issues in those spheres as interconnected thus they have to be dealt simultaneously. Hillary expects all society members, men and women, to be involved in overcoming those issues since women's empowerment supports human advancement as well.
\end{abstract}

Keywords: Hillary Clinton, women issues, women empowerment. 


\section{Introduction}

The condition of women has been transforming from time to time. Still, the common stereotypes that women are more subordinate than men lead the society and even women themselves to forget the fact that they are all the same human being that are born with the same rights to live, have their basic needs fulfilled, and make their own life decisions. It is kind of ironic, seeing that women actually encompass the largest group in the world, which means they also hold a vital position in society.

The United States of America itself, as a country that believes in egalitarian value, is inescapable from this problematic condition for women. Basically, the law in the U.S. has been accommodated to protect women from inequality. Women are now allowed to get access to education, employment, and politics and to receive equal treatment before the law. Even so, as the U.S. is a part of Western Civilization which relies on the patriarchal system, women are still seen as a minority group in the social order and viewed as dependent, weak, and submissive by nature (Johnson 86). Hence, women's subordination is difficult to overcome.

"Women's rights are human rights" was the phenomenal phrase said by Hillary Clinton or Hillary, one of the prominent American women's rights activists in her speech at United Nations $4^{\text {th }}$ World Conference on Women in 1995 to promote equal rights for all. Hillary agrees that those phrases became 'a manifesto for women all over the world' (Gerth and van Natta, 2007; Abrams, 2009). Generally speaking, most of Hillary's speeches contain an inspiring 'can do' attitude that is stated by Shambaugh (2010) as one of her biggest assets as a public figure. She also has the tendency to deliver her speeches with a strong optimist feminism feeling. Lewis argued that Hillary frequently, "[emphasizes] what women can do rather than what they are kept from doing, or their victimization... What seems to be clear is that Clinton chooses to celebrate women's successes rather than their struggles". In addition, Muir and Benitiz also agreed that, "Hillary succeeds in appreciating other women who have made a difference in politics and in society" (as cited in Burrell, 2001). In general, Hillary's speeches focus on both the empowerment and victimization of women.

A lot of researches have discussed about Hillary and/or women issues but not many studies talk about Hillary's viewpoints of women's issues in general, other kinds of women's issues she encounters besides in politics and the solutions for women's issues from her speeches. Take for examples Scharrer (2002) in "An Improbable Leap": A Content Analysis of Newspaper Coverage of Hillary Clinton's Transition from First Lady to Senate Candidate, Wachyuni (1998) in The Role of American Career Women in the Late 20 $0^{\text {th }}$ Century: A Study on Hillary Rodham Clinton, Carlin and Winfrey (2009) in Have You Come a Long Way, Baby? Hillary Clinton, Sarah Palin, and Sexism in 2008 Campaign Coverage, and Leslie (2013) in Hillary Clinton is the only Man in the Obama Administration: Dual Character Concepts, Generics, and Gender. All of them only focus on women's roles and issues in politics.

America as a democratic country has provided laws that support equality for all 
but women's subjugation still emerges. This condition suggests that the law has not overcome women's issues. This phenomenon turns into the major trigger to do a research about this situation. This research intends to analyze women's issues according to Hillary in her speeches. Therefore, the problem of the article is formulated in one big question: "What are Hillary Clinton's views about women issues that are found in her speeches from 2007-2013?"

\section{Methodology}

To acquire a comprehensible picture of women issues's in Hillary's speech, two American Studies approaches are used here; interdisciplinary and reconciliation of tenses. American Studies tries answering a question that is too complex to be dealt with only a single discipline by integrating other disciplines like anthropology, sociology, literature, politics, social, and economic structure, to construct a more comprehensive understanding (Smith, 1980). Meanwhile, reconciliation of tenses approach shows that time is not identical but a continuous and dynamic motion that relate is interrelated, which are past, present, and future (McDowell, 1948). This makes this research focus not only on the historical study that deals with the past but also acts as the bridge for the future (McDowell, 1948).

The theories used in this research are socialist feminism and patriarchy. Most of socialist feminists believe that women's oppression happens due to "class-based capitalism and its alignment with the patriarchal family in capitalistic societies" (Lindsey, 2010). Meanwhile, patriarchy can be defined as an ideology or a social system that promotes male privilege based on the principles of male dominance, male identification, and male centeredness. As a result, it has the characteristics to; (1) be obsessed with control and (2) support the oppression of women to maintain male privilege (Johnson, 1997).

This research is a library research that tries to explore and understand the meaning individuals or groups ascribe to a social or human problem (Creswell, 2009). The data are Hillary's speeches from 2007-2013 found in The American Presidency Project from

http://www.presidency.ucsb.edu/index.php and the U.S. and Department of State from http://www.state.gov/. The research covers speeches written from the year 2007-2013, which are considered as Hillary's golden years in politics as she became a major public figure when she announced her plans to run for the presidency as a democrat in 2007-2008 and when Barrack Obama became the president of the U.S. he appointed her as Secretary of State, a role which she served from 2009-2013.

The data is selected based on maximum variation sampling is used as the approach here. Creswell stated (2009) that this approach determines, "in advance some criteria that differentiate the sites or participants, and then selecting sites or participants that are quite different on the criteria". This approach was selected because it is ideal to show various perspectives on the research problem. Since the data are taken from the Internet, they have no page numbers which makes it difficult to quote some statements in the speeches. The data, as a result, are decided to be combined into the form of a book. The details and arrangements of the 
speeches in the book, such as the title, place, and dates, and the abbreviation of those speeches when they are addressed later in the analysis of this research can be seen in the following tables:

Table 1.1

Speeches as Presidential Nominee for

Analysis

\begin{tabular}{|c|c|c|c|}
\hline \multicolumn{4}{|c|}{ Presidential Nominee for Democrat Party (PN) } \\
\hline Speech Title & Place & Date & Abbreviation \\
\hline $\begin{array}{l}\text { Remarks in the } \\
\text { "Equal Pay } \\
\text { HillCast" }\end{array}$ & (Unknown) & March 6, 2007 & PN No. 1 \\
\hline $\begin{array}{l}\text { Speech and Q\&A } \\
\text { on Innovation }\end{array}$ & $\begin{array}{c}\text { Silicon Valley, } \\
\text { California }\end{array}$ & May 31,2007 & PN No. 2 \\
\hline $\begin{array}{l}\text { Mary Louise Smith } \\
\text { Lecture }\end{array}$ & $\begin{array}{l}\text { The Catt Center for } \\
\text { Women and Politics } \\
\text { at Iowa State } \\
\text { University in Ames }\end{array}$ & October 24,2007 & PN No. 3 \\
\hline $\begin{array}{c}\text { Remarks on } \\
\text { Student Activism }\end{array}$ & Wellesley College & November 1, 2007 & PN No. 4 \\
\hline $\begin{array}{l}\text { Remarks at the } \\
\text { Global Summit on } \\
\text { AIDS and the } \\
\text { Church }\end{array}$ & $\begin{array}{l}\text { Saddleback Church } \\
\text { in Lake Forest, } \\
\text { California }\end{array}$ & November 29, 2007 & PN No. 5 \\
\hline $\begin{array}{l}\text { Remarks on } \\
\text { Foreign Policy }\end{array}$ & $\begin{array}{c}\text { George Washington } \\
\text { University in } \\
\text { Washington, DC } \\
\end{array}$ & February 25, 2008 & PN No. 6 \\
\hline $\begin{array}{l}\text { Remarks in } \\
\text { Grafton }\end{array}$ & $\begin{array}{c}\text { Grafton, West } \\
\text { Virginia }\end{array}$ & May 11, 2008 & PN No. 7 \\
\hline $\begin{array}{l}\text { Remarks Following } \\
\text { the Kentucky and } \\
\text { Oregon Primaries }\end{array}$ & Kentucky & May 20, 2008 & PN No. 8 \\
\hline $\begin{array}{c}\text { Remarks on } \\
\text { Counting Every } \\
\text { Vote at a "Solutions } \\
\text { for America" event }\end{array}$ & Boca Raton, Florida & May 21, 2008 & PN No. 9 \\
\hline $\begin{array}{c}\text { Remarks } \\
\text { Conceding the } \\
\text { Democratic } \\
\text { Presidential } \\
\text { Nomination } \\
\end{array}$ & $\begin{array}{l}\text { National Building } \\
\text { Museum, } \\
\text { Washington D.C. }\end{array}$ & June 7, 2008 & PN No. 10 \\
\hline
\end{tabular}

Table 1.2

Speeches as Secretary of State for Analysis

\begin{tabular}{|c|c|c|c|}
\hline \multicolumn{4}{|c|}{ Secretary of State (SS) } \\
\hline Speech Title & Place & Date & $\begin{array}{c}\text { Abbreviatio } \\
\text { n }\end{array}$ \\
\hline $\begin{array}{c}\text { Remarks with Secretary of } \\
\text { Agriculture Tom Vilsack and } \\
\text { Kenya's Minister for } \\
\text { Agriculture William Ruto }\end{array}$ & $\begin{array}{l}\text { Kenya } \\
\text { Agricultural } \\
\text { Research } \\
\text { Institute }\end{array}$ & $\begin{array}{c}\text { August } 5 \text {, } \\
2009\end{array}$ & SS No. 1 \\
\hline $\begin{array}{c}\text { Opening Remarks at } \\
\text { Combating Violence against } \\
\text { Girls Event } \\
\end{array}$ & New York City & $\begin{array}{c}\text { September } \\
25,2009\end{array}$ & SS No. 2 \\
\hline $\begin{array}{c}\text { Remarks on the 15th } \\
\text { Anniversary of the } \\
\text { International Conference on } \\
\text { Population and Development }\end{array}$ & Washington DC & $\begin{array}{c}\text { January } 8, \\
2010\end{array}$ & SS No. 3 \\
\hline $\begin{array}{c}\text { Remarks at the UN } \\
\text { Commission on the Status of } \\
\text { Women }\end{array}$ & $\begin{array}{l}\text { UN Headquarters } \\
\text { New York City }\end{array}$ & $\begin{array}{c}\text { March 12, } \\
2010\end{array}$ & SS No. 4 \\
\hline $\begin{array}{l}\text { Gala Dinner Celebrating the } \\
\text { U.S.-Islamic World Forum in } \\
\text { the event hosted by the } \\
\text { Brookings Institution and the } \\
\text { State of Qatar }\end{array}$ & Washington DC & $\begin{array}{l}\text { April 12, } \\
2011\end{array}$ & SS No. 5 \\
\hline $\begin{array}{l}\text { Remarks at UNESCO Global } \\
\text { Partnership for Girls' and } \\
\text { Women's Education }\end{array}$ & Paris, France & $\begin{array}{l}\text { May 26, } \\
2011\end{array}$ & SS No. 6 \\
\hline $\begin{array}{c}\text { Remarks at Women } \\
\text { Enhancing Democracy Event }\end{array}$ & $\begin{array}{l}\text { Presidential } \\
\text { Palace Vilnius, } \\
\text { Lithuania } \\
\end{array}$ & $\begin{array}{l}\text { June } 30 \\
2011\end{array}$ & SS No. 7 \\
\hline $\begin{array}{l}\text { Remarks at the APEC Women } \\
\text { and the Economy Summit }\end{array}$ & $\begin{array}{c}\text { Westin Saint } \\
\text { Francis San } \\
\text { Francisco, CA } \\
\end{array}$ & $\begin{array}{c}\text { September } \\
16,2011 \\
\end{array}$ & SS No. 8 \\
\hline $\begin{array}{c}\text { Keynote Address at the } \\
\text { International Crisis Group's } \\
\text { "In Pursuit of Peace" Award } \\
\text { Dinner }\end{array}$ & $\begin{array}{c}\text { Pier Sixty at } \\
\text { Chelsea Pier } \\
\text { New York, NY }\end{array}$ & $\begin{array}{l}\text { December } \\
16,2011\end{array}$ & SS No. 9 \\
\hline $\begin{array}{c}\text { International Efforts To } \\
\text { Empower Women and Girls } \\
\text { Through Sports with ESPN }\end{array}$ & $\begin{array}{c}\text { Treaty Room } \\
\text { Washington, DC }\end{array}$ & $\begin{array}{l}\text { June 21, } \\
2012\end{array}$ & SS No. 10 \\
\hline
\end{tabular}

The speeches gathered are then analyzed based on qualitative analysis steps. The steps are; (1) categorizing strategies in context (such as coding and thematic analysis); (2) contextualizing strategies in which Fairclough's model of Critical Discourse Analysis (CDA) is utilized; and (3) using memos and displays for reflection on theory, method, or purposes, and facilitating the relationships in data (Maxwell as cited in Bickman and Rog, 1997).

\section{Findings}

Hillary declares that women's rights are human rights-the rights that are the real core of human beings, and that means women have the right to work, pursue an education, start a business, and be active in the nation's affairs (PN No. 5, 2007). Even so, Hillary believes that women's empowerment in the world is not only about morality and justice but also about a political, economic, and social imperative (SS No. 4, 2010). It is impossible to develop the world by abandoning the rights of more than half of the population of the world, which are girls and women.

The data reveals women's issues can be classified into five categories; economy, education, health, political, and social to make it easier to detect the views, examples of issues, and solutions about them. Nonetheless, Hillary's speeches point out women issues in those five categories are in fact interrelated, and therefore, they have to be dealt at once. She states, "Because we think changing the conditions of women and girls must go hand-in-hand; their economic, political, and social empowerment must be addressed simultaneously" (SS No. 7, 2011). Empowering women only in one sphere at one time actually does not 
overcome women's issues effectively and efficiently.

\section{Economy}

Hillary clarifies that, "there are still too many millions of girls and women who are uneducated, unhealthy, unfed, as well as treated inhumanly" (SS No. 4, 2010). Meanwhile, to enhance the progress of all humankind, the progress of women should be improved as well. In doing so, Hillary states clearly that it is really important for women to be involved actively in economy for the reason, "When we liberate the economic potential of women, we elevate the economic performance of communities, nations, and the world" (SS No. 8, 2011). Women's participation in economy improves economic efficiency and competitiveness.

In the U.S. itself, Hillary highlights that the main problem is women still earn less money than men for doing the same jobs. She describes that:

Women who work full time year round earn just 77 cents for every dollar that a man makes [for 60 minutes of the hour]. And for women of color it's even less. Sixty-seven cents for African American women for every dollar a man makes. And just 56 cents for Latinas. (PN No. 1, 2007)

Rising wages nowadays are actually desirable considering that energy costs are getting higher so the cost of daily needs is swelling up. The lack of equal income women actually impacts the family's income as well.

While in the international context, Hillary mentions that the common problems that some women face are that they are one of the biggest unemployed groups in worldwide average (SS No. 5, 2011). According to Allais, unemployment is "not only a waste of human resources, a source of public social security deficits or a depressive element for global demand; it is also a threat of disruption to our modern democratic ethos" (as cited in Branco, 2009). Hillary believes that, "women who are free to involve in economy become one of the key drivers of economic growth and social progress create a more stable, peaceful, and secure country" (SS No. 4, 2010).

Hillary offers several solutions to overcome women's issues in the economy. For the U.S., Hillary proposed a new bill called the Paycheck Fairness Act that purpose was to overcome the payment gap between men and women (PN No. 1, 2007). The bill, will toughen the penalty for violating the Equal Pay Act, ensure the government to enforce equal pay laws in the federal contracts, prohibit the employers from retaliating against employees who share salary details, and require the Department of Labor to continue disseminating information about women workers (PN No. 1, 2007). From that, it can be seen that Hillary believes all people deserve equal access to employment, thus they also deserve equal rewards for doing the same job. She wants to ensure people's right to pursue happiness. All of this reflects her belief as a Democrat who favors government's involvement to guarantee people's welfare.

While for international women's issues, Hillary mentions several solutions. Although women's condition generally have improved better than before, Hillary 
thinks that the awareness of women's vital contribution to the world's economy is still low. As a result, Hillary supports the adoption of a declaration for APEC nations that affirms the APEC members' commitment "to improving women's access to capital and markets, to building women's capacities and skills, and to supporting the rise of women leaders in both the public and private sectors" (SS No. 8, 2011). The declaration can be realized in various programs that support women to participate in the economy.

The U. S. government itself, as explained by Hillary, has two programs for expanding global economy; Pathways to Prosperity and the African Women's Entrepreneurship Program (AWEP) (SS No. 8, 2011). Those programs try to involve the entrepreneurs, women in particular, in the economic process by examining and reforming the regulatory systems that rule out their participation and by assisting and facilitating women in entrepreneurship.

Besides presenting programs that are believed to overcome issues in economy, Hillary also expects that increasing the awareness of women's important role in the economy can create a paradigm shift in the society about women. The paradigm shift can be achieved by changing the attitude of the lawmakers, business investors, and consumers toward women (SS No. 8, 2011). However, changing their attitudes is not easy since the formal and informal barriers that prohibit women's participation in economy in the world, whether as employees or entrepreneurs, still exists (SS No. 8, 2011). Both barriers rule out women's participation in economy.
The formal barriers here can be categorized as structural impediment such as the laws, policies, and the government and social institutions system. Whereas, the informal barriers can be categorized as the social impediments, such as patriarchal culture, that regards women as incapable to have jobs, earn money, and be independent, or that women are in danger when they participate in economy due to the belief that women are the moral guardians of the family whose purity and goodness have to be protected (Collins, 2009).

These barriers come from the old economic concepts that have not adapted to the new economic realities or concepts of justice (SS No. 8, 2011). Those old concepts, as Hillary believes, were created in order to maintain men's higher role in supporting the family (SS No. 8, 2011). As a formal institution, government is the one who should secure the right to work through overcoming those barriers as it is where the policy instrument is decided.

All of these views and solutions presented by Hillary to overcome women's issues in economy, in both U.S. and international context actually reflect the ideology of Democrats. By urging all people that economy participation is for everyone, including women, plus by including the governments' participation to ensure equal economic opportunity; they all are comparable with Democrats' idea that government has to accommodate its underprivileged citizens' economy and other life aspects to ensure equality wellshared.

Overall, for women's issues in economy, according to Hillary there is a direct 
correlation between the gender gap and economic productivity, the lower the former then the higher the latter (SS No. 8, 2011). In this $21^{\text {st }}$ century where information is no longer limited by any borders, Hillary believes that the economy participants' age, gender, or other characteristics is not important anymore (SS No. 8, 2011). Everyone is contributing as the participants and valued member of global economy today (SS No. 8, 2011). Women can help lifting up a country's economy activities for sure.

\section{Education}

Hillary supports the idea that all human beings must be able to get easy access to education. She explains that the power to learn, discover, grow, and reach one's Godgiven potential is the heart of human dignity (PN No. 5, 2007). When women are given the rights and opportunities in education,

...the benefits are not just economic. More education leads to more choices, opportunities, and useful information in how to live one's life. Birth rates, HIV infection, incidents of domestic violence, female-cutting all decline when education rises. Fully one half of the drop in child mortality achieved between 1970 and 1990 can be attributed to increased education for women and girls. (SS No. 6, 2011)

Gaining education gives benefit in many spheres. Educating girls and women, is not only the right thing to do, but also the smart one (SS No. 6, 2011).

For the U.S. region, Hillary notices the skill shortage in STEM (Science,
Technology, Engineering, and Math). Even if women can enter college nowadays, the common problem that exists is the lack of women's participation in STEM subjects. There are only a few women who major in those fields. Women actually can contribute as much as men can in those fields. By joining more women, newer perspectives and talents that can enrich a nation's research and discoveries can be obtained.

For international women's issues in education, Hillary remarks that women still represent around two-thirds of the nearly 800 million illiterate adults (SS No. 6, 2011). Besides women, Hillary explains that 72 million children, mostly girls, are still unable to enter schools, and hundreds of millions only finish primary school (PN No. 5, 2007). Education for girls and women even for one extra year, in fact, shows a significantly higher wage for women and girls, that is also increasing their, the families, communities, and country's living standard.

Hillary has several solutions in defeating women's issues in the education sphere. In the U.S., the pressure that comes from women's inability to compete and create new innovations in those fields like men makes them even more unwilling to major those subjects. Hence, Hillary tries gaining public awareness by telling about the falling innovation infrastructure and skill shortage in STEM, and convincing other women to be interested to take those fields as their major (PN No. 2, 2007).

Meanwhile, for international women's issues in education, particularly related to literacy, there are several commitments that the U.S. government has to ward off 
the issue, as stated by Hillary. The U.S., for the instance, has partnered with the NGO Room to Read to support girls in South Asia who are at risk of dropping out of school (SS No. 6, 2011). The partnership has invested in school necessities, mentoring programs, tutoring and community organizing (SS No. 6, 2011).

The barriers in U.S. and international education, as it can be seen, are related to the society's view that women still cannot compete, either in education in general, STEM subjects, or even sports, just like men can. This reveals that apparently the belief that women's competency are in fact as good as men's is not spreading widely enough in the society. Thus the gender barriers in education that prohibit women from achieving their potential still exist.

Getting proper education can help women end their issues not only in education sphere but also in economy, health, politics, and social spheres. As the result, education can provide a solid foundation for active citizenship and social stability, increase social equity, prevent social exclusion, and strengthen the democratic social structures (Singh, 2005; Dufour and Curtis, 2011). Hence, the society, not only women themselves, must work together to overcome women's issues in the education sphere.

\section{Health}

Women and health are one of Hillary's main concerns in her speeches. Women's improved health can create families, communities, and even the nation's stability, sustainability, and development (SS No. 3, 2010). Hillary believes that in eliminating women's issues in the health sphere, the active agent that is expected to fight for women's proper healthcare is merely not women themselves, but also men; it is based on the belief that men's health is also connected to women's (SS No. 3, 2010).

For the U.S. women's health issues, Hillary does not focus merely on women themselves. She tends to see the issues faced in the health sphere as problems for all men, women, and children. To make the health system better in the U.S., Hillary sees that it is appropriate for family leave system to be boosted up. Improving family leave can protect the rights of people, mostly women, and allow them permission from their workplace to look after their sick family member.

Interestingly, Hillary thinks U.S. and international women's issues to some extent are related with each other. For example, Hillary sees that the spread of HIV/AIDS infection in both the U.S. and worldwide are related. Hillary expresses her concern that in the U.S. the infection rates of HIV/AIDS are increasing in poor, communities of color, and women. Similarly, the HIV/AIDS infection has also been increasing in younger women in developing countries (SS No. 3, 2010).

There are also four other common health issues that have to be faced by women in the worldwide setting. They are; difficulties in getting health care access, lack of family planning, and the unavailability of reproductive health and maternal healthcare (SS No. 3, 2010). In Hillary's speeches, women's health care access are often abandoned by the society due to gender and sometimes class 
barriers. In many developing countries many societies invest more on men because they are seen as more productive.

There are several solutions suggested by Hillary for U.S. and international women's issues in health sphere. For health issues in the U.S. in regards to medical leave issues, Hillary believes that it is important to expand the conditions in the Family and Medical Leave Act (PN No. 1, 2007; PN No. 7, 2008). Apparently, this act has not covered several conditions that are really vital for American families yet. For example, this act is not effective enough in preventing people from losing their job when they frequently ask permission not to go to work in order to care for their newborn, sick, handicapped, or aging family member.

For HIV/AIDS infection, since Hillary considers health of women in the U.S. and worldwide as interrelated, due to facing the same challenges in handling HIV/AIDS infection, Hillary had an agenda when she acts as the Presidential candidate that consisted of four steps to deal with this disease. First, she wanted to deal with HIV/AIDS infection in Africa first then later in the U.S. It can be seen that Hillary wanted to prioritize the African region, where HIV/AIDS infection spreads widely.

Hillary also considered that it was necessary for the government to invest in HIV/AIDS treatments, improve health systems in Africa, and double the number of people receiving anti-retroviral treatment, using the $\$ 50$ billion fund that would be allocated if she was chosen as the U.S. President (PN No. 5, 2007). Then, Hillary also thought that targeting motherto-child transmission issues was also essential. It was believed that although the spread of the virus from mother to child could be stopped, the resources and system behind producing and delivering the drugs was still lacking (PN No. 5, 2007). Thus, voluntary testing with counseling for HIV/AIDS patients was recommended (PN No. 5, 2007).

The next step was that the government would invest in education to prevent the infection by teaching young men and women to be more responsible in protecting themselves. The third step in Hillary's agenda was that the government would also continue investing in researches that could develop an effective vaccine and a cure (PN No. 5, 2007). For the final step, Hillary would restart the battle against HIV/AIDS in America (PN No. 5, 2007). Hillary's agenda invited all parties, either the government, society, scientists, and academicians, to participate against this disease. In addition, Hillary also emphasized the importance for the government to embrace the social communities, like churches when dealing with HIV/AIDS.

Meanwhile, to overcome the gender and class issues for international women in receiving health care access, Hillary sees that it is important to change people's common paradigm to reshape the society's misconception about women. Social factors, such as the cultures in understanding the importance of health for all people often play an important role. Cultures, especially the society that adopts patriarchal culture, often create the differences in comprehending how healthcare should be delivered and who should receive it. 
For the practical solutions in getting health care access, family planning, reproductive health, and maternal healthcare, when acting as Secretary of State Hillary often offered one answer; The Global Health Initiative. She stated at the time that U.S. government “is integrating women's issues as a key elements of our foreign policy agenda and in, especially, our Global Health Initiative" (SS No. 3, 2010). This initiative is a part of Millennium Development Goal 5 for mothers' health, which also contains another program to handle HIV/AIDS infection.

Since women and children are often treated as the weakest members of society, the government's role in maintaining their health is vital. Hillary's solutions for U.S. and international women's issues in the health sphere shows her Democrat ideology; that the government wished to be involved actively in overcoming those issues. It is supported by Goldsteen, Goldsteen and Graham (2011) that the governments "have the resources [such as fund, partners, media, etc.] and legal authority to implement public health policies and focus on public health missions that private actors generally lack."

Eliminating women's issues in the health sphere does not only help women, but all members of society. Hillary believes that; "investing in the health of women, adolescents, and girls is not only the right thing to do; it is also the smart thing to do" (SS No. 3, 2010). Goldsteen, Goldsteen, and Graham (2011) suggested the same idea; it is the government, public, and private's obligation to maintain and improve the health of the people using the necessary means and method within a jurisdiction. So, it is important for all members of society to care about the inadequate healthcare women get and to try finding ways to fix it.

\section{Politics}

Politics is about the process, substance, and impact of decision making (Munrou, 2002). Politics, basically, can be performed by anyone. It is important for women to be involved in politics so their voice will always be heard and the development of laws that guarantee their freedom can be monitored (PN No. 3, 2007). Therefore, a nation where every child and adult can achieve his or her God-given potential and dream can be built.

Women's participation in politics is still considered low; meanwhile democracy without women is not exactly a democracy. Take for example women in the U.S. If women were silenced in the past by others, nowadays women are silenced by themselves. Hillary notes that more than 35 million U.S. women still did not vote in 2004 (PN No. 3, 2007). It is important that they use their political rights to vote for people who represent U.S. ideology. When women do not vote, they give up their beliefs, freedom, and right to disagree with people who do not share their beliefs.

Until today, in certain cases international women's voices are also "underrepresented or absent altogether" (SS No. 7, 2011). When women want to participate in politics, they have to endure the isolation, intimidation, and violence. In some parts of the world, women are even denied access to power structures (SS No. 9, 2011). They also often get exclusion from decision-making progress which makes 
them unable to contribute fully in politics. It is important, in fact, to involve them because it is also their future that is being discussed and decided.

Besides isolation, violence is usually used as a political tactic to gain certain political objectives. The objectives can be in the form of preventing women's participation in politics and maintaining men's authority. Hillary exemplifies that there are many cases where "sexual violence is used by governments [often ruled by men] to intimidate and punish protesters seeking democratic reforms ..." (SS No. 7, 2011).

Regarding the issues in politics, Hillary offers several solutions. For issues in the U.S., Hillary tries to gain U.S. citizens' awareness by constantly reminding people that voting is important (PN No. 3, 2007; PN No. 4, 2007; PN No. 10, 2008). Hillary mentions her belief that "politics is the art of making what appears to be impossible possible" (PN No. 4, 2007). Even if actually human are born free and equal, in reality they still have to be protected. The protection can be gained through politics.

For increasing international women's participation in the political process, an active effort is needed to protect women when they participate in politics (SS No. 7, 2011). Either when she acts as a Presidential nominee or Secretary of State, she keeps on saying that human rights including women's have to be in the U.S. foreign policy (PN No. 4, 2007; PN No. 6, 2008; SS No. 3, 2010). Hillary explains that women, their issues, and their improvement have been involved in the U.S. agenda. U.S. foreign policies have adopted the principle of Millennium Development Goal Number 3 that promotes gender equality and the empowerment of women as well.

The U.S. government itself, Hillary continues, also consults women about the design and implementation of U.S. policies, diplomacy, and defense that will give benefits to women (SS No. 4, 2010). In addition, the government will support women leaders' work and evaluate the progress. U.S. government considers women's suppression as a threat to the security of the world because it causes nations' instability (SS No. 4, 2010). Hillary hopes the U.S. will be the leading country that stands up for women because it is in line with U.S. beliefs and values.

She considers that any gender-based violence against girls and women due to political tactics is intolerable. It gives bad impacts to women, particularly to their life. The U.S. government has tried to protect human rights through diplomacy, development, and defense (SS No. 2, 2009). Any excuses that allow the act of violence, including in relation to cultures and religions, will not be accepted. Hillary urges governments of the countries where the violation cases happen to bring the people who are accountable to justice through transparent investigation (SS No. 7, 2011). This way of thinking shows her Democrat belief that the U.S. government should only use its military force when it is necessary.

From Hillary's views, types of women's issues, and solutions, it can be seen that women's ability to participate in politics actively is still hindered by male domination. Politics in fact hold vital keys for them to achieve equality for all. Many policies and decisions related to many 
spheres, such as economy, education, or health that supports all human rights can be acquired or reinforced through politics. Hence, Hillary believes that to achieve an ideal democracy, one of the ways is that women can use their rights to vote and to run for public office actively so that the government is more effective in response to people (SS No. 4, 2010). Women should not let their rights to participate in politics be wasted.

\section{E. Public life}

A society usually comprises of individuals whose lives are governed by religious, political, economic, and organizational rules that share certain structures, cultural norms, values, and beliefs (Goldsteen, Goldsteen, and Graham, 2011; Johnson, 1997). The term social used here focuses on the way the individuals live, and their relationship with other individuals and environment. In Hillary's speeches, she discusses about women's relationship with other society members based on social factors, such as gender and class, within a patriarchal society.

Overall, Hillary's views, types of women's issues, and solutions in the life spheres mentioned before reveal that the main cause of women's suppression in the society is because of the patriarchal culture. She discusses how patriarchal culture supports women's subordination. In 2010 she states that, "in too many places, women are treated not as full and equal human beings with their own rights and aspirations, but as lesser creatures undeserving of the treatment and respect accorded to their husbands, their fathers, and their sons" (SS No. 4, 2010). It is easier to allow women to blend into patriarchal society than to challenge it. When women begin to, they are frequently ignored, rejected, or even worse, oppressed.

Unfortunately, gender discrimination is also supported by the government in some countries. As explained before, patriarchal culture leads men to have high control in every life aspect, including in legal institutions. Government is a state institution that basically has to protect every single citizen but since the majority of politicians and officials are men, the law often prioritizes maintaining male privilege.

Another issue for women in a patriarchal culture emerges as well. There is a misconception of women spreading in the society. This misconception causes the members of the patriarchy society, which are children, men and women themselves, to subconsciously have the perspective that women are second-class society member in which their status is lower than men's. Hillary explains that she herself experiences that kind of misconception; women are seen only as a homemaker, rarely as an educated and career woman (PN No. 4, 2007; PN No. 3, 2007).

Misconception, ominously, creates the perception that women oppression as something normal and natural (PN No. 5, 2007). The normalization of women oppression, unfortunately, also leads the society to have a tendency to blame women themselves for being easily oppressed. Hillary provides a case sample:

... Mukhtar Mai, a young woman who I've come to know, who was gang-raped in 2002. . . . She was forced to walk home naked in front her village, and she was expected 
to kill herself. I mean, that's what you do. You get humiliated, you get shamed, you get attacked. It's your fault, you go kill yourself. (SS No. 2, 2009)

The society's view that women should be responsible for the oppression shows how male dominance operate in a patriarchal culture; that men are always highly valued and easily free from the blame.

There is one main solution offered to overcome the women issues in social sphere by Hillary. Basically, Hillary sees that it is important to change the misconception of women by reshaping a new paradigm (SS No. 5, 2011; SS No. 8, 2011). Hillary always tries to change the misconception, either when she acts as Presidential nominee or Secretary of State by constantly informing, reminding, and arousing public's awareness that women are also human being and one of important keys for families, communities, nation, and even humankind's advancement (PN No. 6, 2008; SS No. 2, 2009; SS No. 3, 2010; SS No. 4, 2010).

Besides rising public's awareness, the new paradigm can also be gained through challenging the patriarchal culture. Patriarchal culture has been existed for so long thus women themselves believe that their oppression as normal,

And I've met girls who have heard their whole lives that they were less than-less talented, less worthy of respect - until they eventually came to believe it was true... The principle of women's equality is a simple,...but the work of turning that principle into practice is rarely simple. It takes years and even generations of patient, persistent work, not only to change a country's laws, but to change its people's minds, to weave throughout culture and tradition in public discourse and private views the unassailable fact of women's worth and women's rights. (SS No. 4, 2010)

Challenging patriarchal culture is not easy. It can be overcome by supporting any actions that promote equality of women in all life aspects. Although the difficulties are persistent, Hillary explains the determination is very vital.

Taken as a whole, women issues in social sphere contain the problems about the relationship between women and men to the social factors like gender and class in a patriarchal society. Those problems are not easy to deal with. Nonetheless, unlike other spheres, this sphere mostly gets in touch with people's mind since the main solution lies in the paradigm shift about women. The society needs to be reminded on a regular basis that women are just like men as a human being. Once the paradigm shift achieved, a great improvement of women condition in many sphere will progress simultaneously.

From all five spheres of women issues discussed in Hillary's speeches above, it is found that in overall women have contributed more in the economy, education, health, political, and social sphere than they did in the past. Nonetheless, their talents, opportunities, and achievements are still hardly acknowledged. All speeches show Hillary's thoughts that everyone has to work hand-in-hand to help overcoming women issues in all spheres as women's advancement also means human's advancement as well. 
This situation also shows Hillary's viewpoint about women issues are actually not the core problem in the society. She believes that women issues are only a part of bigger issues in improving the life of humankind that need to be abolished. She suggests this idea in several occasions, whether when she acts as a Presidential nominee for Democrat party or Secretary States. She always explains that women's progress is human progress, and human progress is women's progress once and for all (PN No. 6, 2008; SS No. 4, 2010).

From the views, types of issues, and solution for women issues that Hillary is performing several roles when addressing women issues. The speeches found that Hillary has acted as a civil right activist, a Democrat who believes in progressivism, and a socialist feminist. As a civil right activist, she attempts to protect any human being's basic rights, including women's from being violated in all life aspects. It is based on the liberalism that emphasizes in upholding the rights of all individuals to have freedom and autonomy (Lindsey, 2010; Tong, 2009; McAuley, 2003).

Hillary is also found in her speeches to show herself as a Democrat Party proponent. Democrat Party relies it political ideology in liberalism. Today's liberalism believes that government action is needed to preserve individual liberty, promote justice, and reduce inequality (Ginsberg, et al, 2011). Democrats, in general, support the government to be more involved in domestic affairs, such as intervening the economy, supporting for federal social services, and helping the poor, minorities, and women, as well as in international affairs such as supporting for aid to poor nations and opposing to the use of American troops to influence the domestic affairs of developing nations (Ginsberg, et al, 2011).

All of the examples of government involvement in public's life above are similar with Hillary's ideas in dealing with women issues. All of her speeches show that she prefers people's right to pursuit happiness that are violated have to be taken care of by the government under the law. She also often discusses women and other minorities' oppression in society to raise public awareness. Most importantly, she also presents many proposals and U.S. programs that help the life of unfortunate people, especially women, in both U.S. and large numbers of developing countries to lift their condition up.

Hillary as a Democrat, who enters the politics world, is aspiring to change the systems that underprivileged people from the inside of the government system. As her political orientation focuses more on progress for the nation and its people toward better condition, she is deemed as a person who believes in progressivism. Progressivism is a belief that changes in social, politics, and economy is vital to improve the lives of people (Eisenstark and Friedenthal, 2010).

As a feminist, Hillary proposes the idea that women subjugation is violating human rights. Changing women's condition "must go hand-in-hand; their economic, political, and social empowerment must be addressed simultaneously" (SS No. 7 129). She argues equality can be achieved by persistent works, law accommodation, and paradigm shift although it will takes some time (SS No. 4 109). As a result, women can gain more power to be autonomous. Hillary regards the structural, cultural, and 
social impediments that are based on patriarchal and capitalistic system are considered as the challenge to women's progress (PN No. 3, 2007; SS No. 8, 2011; SS No. 9, 2011).

All of these statements that reflect Hillary's views about women issues make her can be classified as a socialist feminist. Her idea reflects this branch of feminism since she believes that patriarchal and capitalistic systems are the causes of women oppression (Chafe 131; Lindsey 15). Changing a society system by changing how society members think, feel, and behave in social relationship is important. Hillary, moreover, thinks that people have to work hand-in-hand to overcome those impediments. Women cannot deal with the issues they have by themselves, and this idea is supported by socialist feminism (Johnson, 1997).

From the view, types of issues and solution that Hillary offers to overcome women issues in her speeches, it can be seen that Hillary wants to promote women empowerment under government's helps so women can have the equal rights to participate in many life spheres with men. They also reflect her roles either as a civil right activist, a Democrat who believes in progressivism and a socialist feminist; they all show that Hillary is influenced by social liberalism. Social liberalism emphasizes in upholding values of individual liberty and social justice that can be achieved when women get equal opportunities to all life spheres by changing the social system under government observation (Ginsberg, et al, 2011).

\section{Conclusion}

When women live in a patriarchal society they experience oppression as patriarchal values men more than them. The oppression occurs in many life aspects; economy, education, health, politics, and social sphere. Hillary sees that it is essential to overcome the oppression by dealing with women issues. However, women issues and their solutions are actually interconnected with each other. Improving one sphere can help other sphere to improve, but to achieve women empowerment effectively and efficiently; the issues in all spheres have to be dealt at once. Simultaneous participation from all members of the society, including men, is needed because the issues will not disappear if women fight them alone. It is also found that overcoming women issues actually grants more benefits than people know commonly, in which human advancement.

\section{References}

Abrams, Dennis. (2009). Woman of Achievement: Hillary Rodham Clinton. Infobase Publishing: New York.

Bickman, Leonard and Rog, Debra, eds. (1997). Handbook of Applied Social Research Methods. Thousand Oaks, CA: Sage.

Branco, Manuel Couret. (2009). Economics versus Human Rights. Routledge.

Burrell, Barbara. (2001). The Public Opinion, the First Ladyship, and Hillary Rodham Clinton. Routledge: New York. 
Carlin, Diana B. and Winfrey, Kelly L. (2009). Have You Come a Long Way, Baby? Hillary Clinton, Sarah Palin, and Sexism in 2008 Campaign Coverage. Communication Studies. Vol. 60, No. 4, p. 326-343.

Chafe, William H. (1977). Women and Equality: Changing Patterns in America Culture. Oxford University Press.

Collins, Gail. (2009). When Everything Changed: The Amazing Journey of American Women from 1960 to the Present. Back Bay Books.

Creswell, John W. (2009). Qualitative Inquiry\& Research Design: Choosing Among Five Approaches ( $\left.2^{\text {nd }} E d.\right)$. SAGE Publications Inc.

Dufour, Barry and Curtis, Will, eds. (2011). Studying Education: An Introduction to the Key Disciplines on Education Studies. McGrawHill Open University Press.

Eisenstark, Reyna and Friedenthal Lora. (2010). Key Concepts in American History: Progressivism. Ed. Jennifer L. Weber. Chelsea House Publishers.

Gerth, Jeff, and van Natta, Jr., Don. (2007). Her Way: The Hopes. Little, Brown, and Company: New York.

Ginsberg, Benjamin, et al. (2011). We The People: An Introduction to American Politics ( $8^{\text {th }}$ Ed.). W. W. Norton \& Company.

Goldsteen, Raymond L., Goldsteen, Karen, and Graham, David G. (2011). Introduction to Public Health. Springer Publishing Company, LLC.

Johnson, Allan G. (1997). The Gender Knot: Unraveling Our Patriarchal Legacy. Temple University Press.
Leslie, Sarah-Jane. (2013). "Hillary Clinton is the only Man in the Obama Administration": Dual Character Concepts, Generics, and Gender (in press). Analytic Philosophy.

Lindsey, Linda L. (2010). Theoretical Perspective and Feminist Frameworks. The Sociology of Gender in Gender Roles: A Sociological Perspective $\left(5^{\text {th }}\right.$ Ed.). Pearson Publishing.

McDowell, Tremaine. (1948). American Studies. Minneapolis: The University of Minnesota Press.

McAuley, James W. (2003). An Introduction to Politics, State and Society. SAGE Publications Ltd.

Munroe, Trevor. (2002). An Introduction to Politcs: Lectures for First-Year Students ( $3^{\text {rd }}$ Ed.). Canoe Press.

Scharrer, Erica. (2002). An "Improbable Leap": A Content Analysis of Newspaper Coverage of Hillary Clinton's Transition from First Lady to Senate Candidate. USA Journalism Studies. Vol. 3, No. 3, p. 393-406.

Shambaugh, Rebecca. (2010). Leadership Secrets of Hillary Clinton. McGraw-Hill eBooks.

Singh, Madhu, ed. (2005). Meeting Basic Learning Needs in the Informal Sector: Integrating Education and Training for Decent Work, Empowerment and Citizenship. Springer.

Smith, Henry Nash. (1980). Can American Studies Develop a Method? Studies in American Culture. Joseph J. Kwiat and Mary C. 
Turpie, eds. Minneapolis: University of Minnesota.

Tong, Rosemarie. (2009). Feminist Thought: A More Comprehensive Introduction. Westview Press.

Wachyuni, Sri. (1998). The Role of American Career Women in the
Late 20 $0^{\text {th }}$ Century: A Study on Hillary Rodham Clinton. (Unpublished Dissertation). Universitas Gadjah Mada. Yogyakarta. 
